\title{
Pengukuran Prestasi Kerja Karyawan Menggunakan Motivasi Pada Badan Pengelolaan Keuangan Daerah Kota Metro
}

\author{
Oleh: \\ Suharto \\ Fakultas Ekonomi Program Studi Manajemen Universitas Muhammadiyah Metro \\ (hartoumm@gmail.com)
}

\begin{abstract}
The aim of this research is to find the relationship between work motivation and employee performance. This research used survey method. The total population is 86 employees. Based on Slovin method, samples taken by random sampling are as much as 70 respondents. The analytical tool used is Rank Spearman correlation, by using hypothesis testing of distribution Z. Based on the calculation results obtained that the work motivation has a significant relationship with employee performance. It means that the higher the motivation of work, the higher the performance of employees.
\end{abstract}

Keywords: Motivation and performance

\section{LATAR BELAKANG}

Pembangunan yang dilaksanakan oleh pemerintah dan bangsa Indonesia dewasa ini merupakan kelanjutan dan peningkatan dari program pembangunan sebelumnya yang secara spesifik menekankan strategi pembangunan pada peningkatan strategi pembangunan pada peningkatan kualitas sumber daya manusia, utamanya adalah kualitas sumber daya aparatur. Hal ini disebabkan aparatur negara bertugas dan bertanggung jawab atas penyelenggaraan pemerintahan, pembangunan dan pelayanan masyarakat serta senantiasa mengabdi dan setia kepada kepentingan, nilai-nilai dan cita-cita perjuangan manusia.

Pembangunan aparatur negara terkait erat dengan fungsi dan peranannya dimasa yang akan datang, yang lebih mengarah kepada profesionalisme kerja, pemberian kemudahan administrasi dan pelayanan masyarakat. Aparatur negara diharapan mampu memberikan dukungan administrasi negara, menjamin kelancaran dan keterpaduan tugas, sehingga dapat melaksanakan tugas pokok dan fungsinya secara optimal, sertatanggap terhadap aspirasi rakyat dan dinamika perubahan yang terjadi. Dengan demikian aparatur negara dapat melaksanakan tugas-tugas pemerintahan dengan baik.

Dalam kaitan reformasi yang berlangsung dewasa ini, aparatur pemerintah harus lebih mencurahkan perhatian kepada pemberian pelayanan yang terbaik kepada masyarakat, serta mengupayakan pelaksanaan tugas secara transparan dan akuntabel. Hal ini baru dapat terselenggara secara sistematis dan konsisten, baik terhadap pembinaan karier maupun prestasi kerja. Dalam rangka inilah pemerintah berusaha agar prestasi kerja dari para karyawan dapat ditingkatkan. Untuk meningkatkan prestasi kerja karyawan, maka pemerintah perlu memperhatikan semangat dan gairah kerja dari para karyawan dengan cara memberikan motivasi.

Seseorang akan bekerja giat untuk memenuhi kebutuhan fisik dan mental. Pemberian motivasi kerja terhadap para karyawan pada dasarnya agar mereka dapat bekerja dengan penuh semangat. Semangat kerja yang tinggi, maka diharapkan karyawan tersebut dapat berprestasi. Mengingat betapa pentingnya prestasi kerja, maka sangat perlu adanya usaha pemberian motivasi yang baik, antara lain: Pemberian jaminan sosial, Pemberian kesempatan, Pemberian insentif, Pendidikan dan latihan, Disiplin kerja, Ravianto (2001).

Berdasarkan survey pendahuluan, diketahui bahwa ketidak hadiran pegawai masih relatif tinggi, dimana ketidak hadiran pegawai tanpa keterangan masih sangat dominan 
dibandingkan dengan memberikan keterangan sakit ataupun izin. Tingkat absensi tertinggi terjadi pada bulan Januari 2015 yaitu sebesar 1,76\% dan terendah pada bulan Mei 2015 yaitu sebesar $0,08 \%$.

Tingkat absensi yang tinggi akan mengakibatkan waktu untuk pencapaian target pelaksanaan pekerjaan semakin berkurang, sehingga tugas tidak dapat diselesaikan pada waktunya. Tingkat absensi yang tinggi juga menunjukan keadaan dimana semangat dan kegairahan kerja pegawai rendah sehingga mempengaruhi prestasi kerjanya.

Bentuk kegiatan Motivasi pada Badan Pengelolaan Keuangan Daerah dalam upaya peningkatan mutu dalam proses maupun hasilnya, Kepala Badan telah melakukan motivasi antara lain: Memberikan gaji yang cukup setiap bulannya menurut jenjang kepangkatan/jabatan yang diuraikan menurut golongannya, memberikan kesempatan kepada karyawan / Pegawai Badan Pengelolaan Keuangan Daerah (BPKD) untuk ikut serta membahas persoalan yang terjadi di lingkungan BPKD dan lingkungan melalui rapat, memberikan kesempatan kepada Karyawan/Pegawai BPKD untuk mengembangkan kemampuan, seperti misalnya dengan mengikuti Pendidikan dan Latihan serta kursus-kursus dengan suatu harapan untuk dapat menduduki jenjang kepegawaian yang lebih tinggi.

\section{KAJIAN TEORITIK Pengertian Motivasi}

Menurut Hasibuan (2001) keberhasilan suatu pekerjaan ditentukan oleh suatu Tenaga Kerja yang ada dalam instansi tersebut. Motivasi dapat diartikan sebagai usaha agar seseorang dapat mengerjakan pekerjaannya. Manusia mempunyai motivasi yang berbeda tergantung dari banyaknya faktor seperti kepribadian, ambisi, pendidikan dan usia. Manusia yang rendah bekerja untuk memenuhi kebutuhan yang didasari (Concious Needs) maupun kebutuhan yang tidak didasari (Unconcious Needs) demikian juga dengan manusia yang hendak bekerja.

Dengan demikian, setiap pekerjaan mempunyai motif atau need tertentu dan mengharapkan kepuasan dari hasil kerjanya. Kebutuhan-kebutuhan yang dipuaskan dengan bekerja antara lain: Kebutuhan fisik dan keamanan, menyangkut kepuasan kebutuhan fisik atau biologis seperti makan, minum dan tempat tinggal. Kebutuhan sosial, karena manusia tergantung satu sama lainnya. Maka terdapat berbagai kebutuhan yang hanya bisa dipuaskan apabila masing-masing individu ditolong atau diakui oleh orang lain, dan Kebutuhan egoistik, ini berhubungan dengan keinginan orang untuk mengerjakan sesuatu sendiri dan untuk kepuasan atas keberhasilan menyelesaikan pekerjaan.

Dengan mengetahui perilaku manusia, apa sebabnya orang mau bekerja dan kepuasan apa yang dinikmatinya karena bekerja. Menurut Ibrahim (2015) seorang pemimpin akan lebih mudah memotivasi bawahannya. Pengertian motivasi akan diberikan para ahli berbeda-beda, namun makna dan maksudnya sama.

Menurut Gr. Terry dalam buku Hasibuan (2001), motivasi adalah kegiatan yang terdapat pada diri seseorang yang merangsangnya untuk melakukan tindakan-tindakan.

Manfaat dari rangsangan motivasi itu adalah: mendorong gairah dan semangat kerja, meningkatkan moral dan kepuasan kerja pegawai, meningkatkan kedisiplinan dan menurunkan tingkat absensi pegawai, meningkatkan produktivitas kerja pegawai, mempertahankan loyalitas dan kestabilan pegawai, mengefaluasi pengadaan pegawai, menciptakan hubungan kerja dan suasana yang baik, meningkatkan kreativitas dan partisipasi pegawai, meningkatkan kesejahteraan pegawai, mempertinggi rasa tangung jawab karyawan terhadap tugas-tugasnya, dan meningkatkan efisiensi penggunaan alat-alat dan bahan baku

Manfaat yang diproleh sangat banyak sehingga peran motivasi kerja mejadi penting pada masa sekarang ini. Motivasi kerja merupakan hal penting sehingga menjadi bagian dari kegiatan perusahaan dalam proses pembinaan, pengembangan dan pengarahan sumber daya manusia dalam bekerja. Pegawai harus memiliki motivasi dalam melaksanakan pekerjaannya sehingga dapat memberikan dorongan agar dapat bekerja dengan giat dan senang melakukan pekerjaannya. 
Menurut Edwin B. Flippo, dalam buku Hasibuan, Melayu S.P. (2001), motivasi adalah suatu keahlian dalam mengarahkan pegawai dan organisasi agar mau bekerja secara berhasil sehingga tercapai keinginan pegawai sekaligus tercapai tujuan organisasi. Hal itu didukung oleh pendapat Ardana, et.al. (2012), motivasi adalah kekuatan yang mendorong seseorang untuk melakukan suatu tindakan atau tidak pada hakekatnya ada secara internal maupun eksternal yang dapat positif atau negative untuk mengarahkannya sangat tergantung kepada ketangguhan sang menajer.

Menurut Pamela (2015), motivasi adalah serangkaian sikap dan nilai-nilai yang mempengaruhi individu untuk mencapai hal yang spesifik sesuai dengan tujuan individu. Sikap dan nilai tersebut merupakan suatu yang invisible yang memberikan kekuatan untuk mendorong individu bertingkah laku dalam mencapai tujuan.

Menurut Herzbery dalam buku Siagian MPA, (2008), motivasi adalah hal-hal pendorong berprestasi yang sifatnya intrinsik yang berarti bersumber dari dalam diri seseorang. Dimana faktor-faktor intrinsik tersebut meliputi: Pencapaian prestasi, Pengakuan, Tangung jawab, Kemajuan, Pekerjaan itu sendiri, dan Kemungkinan berkembang

Menurut Ardana, et.al. (2012), jenis-jenis motivasi pada dasarnya jenis motivasi tersebut dapat dibagi tiga yaitu: material incentive: pendorong yang dapat dinilai dengan uang, semi material incentive, non material incentive : yang tak dapat dinilai dengan uang, seperti: penempatan yang tepat, latihan sistematik, promosi dan objektif, pekerjaan yang terjamin, keikut-sertaan wakil-wakil karyawan dalam pengambilan keputusan, kondisi pekerjaan yang menyenangkan, pemberian informasi tentang perusahaan, fasilitas rekreasi, penjagaan kesehatan.

Perubahan pemberian motivasi bagi seseorang akan berbeda atau tidak akan sama hasilnya jika diberikan kepada orang lain. Dengan kata lain, suatu dorongan yang efektif bagi seseorang belum tentu efektif bagi orang lain.

Manajer ingin merasangsang atau mendorong para bawahan untuk dapat bekerja dengan giat, harus mempelajari dan mengenali setiap bawahannya. Agar bisa menggunakan tipe motivasi yang tepat, menurut Wiludjeng (2007), bahwa motivasi dapat dibedakan menjadi beberapa kelompok :

a) Motivasi Positif, adalah merupakan dorongan terhadap karyawan yang dapat berupa misalnya hadiah, pujian, insentif, piagam dan lain sejenisnya.

b) Motivasi Negatif, adalah dorongan terhadap karyawan atau bawahan yang biasanya berupa ancaman dan hukuman.

Pada jenis pertama, pimpinan memberikan kemungkinan memperoleh hadiah terhadap hasil yang telah dicapai oleh bawahannya yang dapat berupa tambahan uang, imbalan dan sebagainya. Sedangkan pada jenis kedua, apabila seseorang tidak melakukan sesuatu seperti yang diinginkan perusahaan, akan mengambil kebijaksanaan untuk memberitahukan bahwa pekerjaan tersebut mungkin akan kehilangan sesuatu seperti misalnya kehilangan pengakuan, uang atau mungkin jabatannya.

Masalah utama dari penggunaan dua jenis motivasi tersebut adalah perimbangan (proporsi) penggunaan dan kapan akan digunakan. Jika seorang pemimpin percaya bahwa ketakutan akan mengakibatkan seseorang segera melakukan tindakan. Maka penggunaan motivasi negative akan lebih sering dan sebaliknya, apabila seseorang pemimpinan percaya kesenangan dapat menjadi dorongan dalam bekerja pemimpin tersebut akan banyak menggunakan motivasi positif.

Pemberian motivasi positif, Ofelia (2016), akan menimbulkan peningkatan semangat untuk mengurangi keluhan dan secara umum mengurangi kesulitan. Penggunaan motivasi negative seringkali memberikan hasil yang lebih banyak, berupa peningkatan produktivitas dalam jangka pendek. Sedangkan motivasi negatif akan lebih berhasil dalam jangka panjang. Motivasi berupa fenomena hidup yang banyak corak dan ragamnya. Secara umum motivasi dapat diklasifikasikan dalam empat jenis yang satu sama lain memberi warna terhadap aktivitas manusia., menyatakan bahwa motivasi yang diberikan dapat berupa berbagai golongan. 
Motivasi timbul karena dua faktor, yaitu faktor dari dalam diri manusia dan faktor dari luar diri manusia. Wursanto (2000), yakni faktor dalam diri manusia (disebut motivasi internal) berupa sikap, pendidikan, kepribadian, pengalaman, pengetahuan dan cita-cita, dan faktor dari luar diri manusia (motivasi eksternal) berupa gaya kepemimpinan atasan, dorongan atau bimbingan seseorang dan perkembbangan motivasi.

Seorang pemimpin yang merupakan motivator yang harus mengetahui tentang motivasi agat keberhasilan organisasi dalam mewujudkan usaha kerja manusia dapat tercapai. Menurut Mangkunegara (2004) bahwa ada dua faktor yang mempengaruhi prilaku manusia, yaitu:

Dari berbagai definisi tersebut, maka dapat ditarik kesimpulan bahwa motivasi adalah kekuatan yang mendorong seseorang melakukan suatu tindakan yang timbul pada diri pekerja waktu dia menjalankan tugas pekerjaannya. Karyawan dapat bekerja karena tertarik dan senang pada pekerjaannya dan merupakan keinginan yang terdapat pada seorang individu untuk melakukan suatu tindakan-tindakan.

\section{Prestasi Kerja}

Salah satu tujuan prusahaan tentunya mengharapkan adanya peningkatan hasil pendapatan untuk mencapai hasil tujuan yang telah ditetapkan, hal ini harus ditunjang dengan semangat dan kegairahan kerja karyawan yang bermotivasi dan bertanggung jawab, sehingga para karyawan dapat berprestasi yang lebih tinggi.Untuk memproleh gambaran yang jelas, penulis memberikan beberapa definisi dari pada dikemukakan oleh pendapat para ilmu pengetahuan tentang Prestasi Kerja.

Menurut Siswanto (2002), Prestasi Kerja adalah hasil kerja secara kualitas dan kuantitas yang dicapai oleh seorang karyawan dalam melaksanakan tugasnya sesuai dengan tanggung jawab yang diberikan kepadanya.

Kuantitas kerja berarti karyawan harus berupaya dengan sekuat tenaga untuk mencapai hasil kerja yang sesuai dengan target.Artinya, karyawan harus selalu menyiapkan kondisi tubuhnya kuat dan sehat, kondisi perasaan dan emosi yang penuh semangat, kondisi pakaian yang jernih, tenang dan kreatif.

Kualitas kerja berarti karyawan harus memiliki mind set, keterampilan, pengetahuan dan niat baik untuk bekerja dengan berkualitas, rapi, bersih, teliti dan indah.

Keberhasilan mengoptimalkan kualitas kerja dan kuantitas kerja sangat tergantung kepada niat dan kemauan karyawan untuk berprestasi. Bila karyawan meemiliki motivasi yang kuat untuk menjadikan diri sendiri sebagai pribadi yang produktif, maka mereka pasti memfokuskan diri untuk kuantitas dan kualitas yang perima.

Setiap orang dilahirkan untuk mencapai apa yang diinginkan. Setiap orang diberi kesempatan oleh kehidupan untuk mencapai semua harapan dan keinginan. Setiap orang memiliki hak untuk menjadi sukses dan menghasilkan keberhasilan dalam hidupnya. Setiap orang hanya bisa sukses bila dia bekerja untuk kualitas dan kuantitas terbaik. Jadi, seekarang waktunya untuk mulai bekerja secara cerdas baut kualitas dan kuantitas terbaik.

Menurut Mangkunegara (2005) Prestasi Kerja adalah suatu hasil kerja yang dicapai seseorangg dalam melaksanakan tugas yang dibebankan kepadanya, yang didasarkan atas kecakapan, pengalaman dan kesungguhan.

Kesatuan akan mendapat kecaakapan, jika anda menghendaki stantar kerja yang tinggi dari perseorangan dan kelompok. Kecakapan sebagian besar didapatkan dari latihan, karena itu sebagai seorang komandan, pengawasan selama latihan membutuhkan sebagian besar dariwaktu anda.Hal ini merupakan salah satu metode yang dapat dipercaya untuk menilai kecakapan dari perseorangan dan kesatuan.

Seseorang yang berpengalaman dalam bekerja meemiliki kemempuan kerja yang lebih baik dari orang tersebut telah belajar dari kegiatan-kegiatan dan permasalahan yang timbul dalam bekerja. Dengan adanya pengalam kerja maka telah terjadi proses penambahan ilmu pengetahuan dan keterampilan serrta sikap pada diri seseorang, sehingga dapat menunjang mengembangkan diri dengan perubahan yang ada. 
Sedangkan menurut Sutrisno (2011) Prestasi Kerja adalah catatan yang diproleh dari fungsi-fungsi pekerjaan tertentu atau kegiatan tertentu selama kurun waktu tertentu. Fungsi kerja adalah melakukan pekerjaan sesuai dengan jabatannya. Setiap jabatan dalam organisasi panitia mempunyai fungsi kerja yang berbeda sesuai dengan bidangnya.

Untuk mengetahui bahwa dalam organisasi perlu ada kerja sama. Kerja sama ini dilakukan secara langsung maupun tidak langsung. Fungsi menunjukan maka dari pekerjaan yang telah dan akan dilakukan. Dalam organisasi fungsi kerja benar-benar sangat diperlukan.Hal ini sangat mengetahui keberhasilan dalam suatu kegiatan atau tujuan organisasi.

Menurut Bas dan Rue, dalam Sutrisno (2011), mengartikan prestasi kerja sebagai tingkat kecakapan seseorang pada tugas-tugas yang mencangkup pada pekerjaannya.

Kecakapan seseorang dalam mencangkup tugas-tugasnya merupakan aspek intelrktual yang berupa suatu kemampuan (potensial dan nyata) dalam mengenal, memahami, menganalisis, menilai dan memecahkan masalah-masalah dengan menggunakan rasio atau pemikiran.

Kecakapan dapat dibedakan menjadi:

Menurut Anoraga (2006) pemahaman tentang prestasi kerja biasa dilepaskan dari pemahaman yang bersifat multi dimensional. Kemauan dan kemampuan yang dimiliki seseorang dalam melakukan pekerjaan dapat dilihat dari prestasi kerjanya dalam usaha penerapan konsep dan gagasan. Ide dengan efektif dan efisien sehingga tercapai tujuan yang ditetapkan oleh perusahaan.Tetapi memimpin dengan mengaplikasikan semua kemampuan yang ada dalam dirinya untuk mencapai tujuan yang telah ditetapkan bersama dalam suatu unit perusahaan.

Berdasarkan pendapat para ahli prestasi tersebut, dapat disimpulkan bahwa prestasi kerja adalah hasil kerja sama disiplin, dan kreatifitas seorang karyawan untuk menghasilkan kualitas dan kuantitas dalam melaksanakan tugasnya.. Memiliki jiwa kepemiminan, serta catatan yang diperoleh dari fungsi-fungsi pekerjaan sebagai tingkat kecakapan, kesetiaan, dan kejujuran seseorang pada tugas-tugas yang mencangkup pada pekerjaannya.

\section{KERANGKA PEMIKIRAN}

Sugiono (2010) menyatakan bahwa "kerangka berfikir merupakan model konseptual tentang bagaimana teori berhubungan dengan berbagaifaktor yang telah diindentifikasi sebagai masalah yang penting".

\section{Motivasi (x)}

Motivasi (x) merupakan kekuatan yang mendorong seseorang melakukan suatu tindakan yang timbul pada diri pekerja waktu dia menjalankan tugasnya. Karyawan dapat bekerja karena tertarik dan senang pada pekerjaannya dan merupakan keinginan yang terdapat pada seorang individu yang merangsangnya melakukan tindakan-tindakan.

2. Prestasi Kerja (y)

Prestasi Kerja (y) merupakan hasil kerja secara kualitas dan kuantitas seorang karyawan dalam melaksanakan tugasnya. Serta catatan yang diperoleh dari fungsi-fungsi pekerjaan sebagai tingkat kecakapan seseorang pada pekerjaannya.

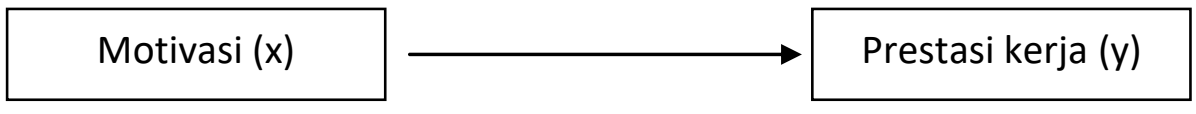

Gambar 2.1 kerangka pemikiran

\section{METODOLOGI PENELITIAN Metode Penelitian}

Metode penelitian pada dasarnya adalah suatu upaya yang sistematis untuk menerangkan fenomena sosial dengan cara memandang fenomena tersebut sebagai hubungan antar variabel. Menurut Sugiyono (2010) menjelaskan bahwa: "Metode Penelitian pada 
dasarnya merupakan cara ilmiah untuk mendapatkan data dengan tujuan dan kegunaan tertentu". Sedangkan pengertian menurut Wirantha (2006) metode penelitian adalah sebagai berikut: "suatu cabang ilmu pengetahuan uang membicarakan atau mempersoalkan cara-cara melaksanakan penelitian (yaitu meliputi kegiatan mencari, mencatat, merumuskan, menganalisis sampai menyusun laporannya) berdasarkan fakta-fakta atau gejala-gejala secara ilmiah".

Metode yang digunakan dalam penelitian ini adalah metode explanatory survey yaitu metode yang bertujuan untuk menguji hipotesis dalam bentuk hubungan antar variabel. Metode analisis yang digunakan dalam penelitian ini adalah Analisis Korelasi Rank Spearman.

\section{Operasionalisasi Variabel}

Operasional variabel merupakan devinisi/uraian-uraian yang menjelaskan dari suatu variabel-variabel yang akan diteliti yang mencangkup indikator-indikator yang ada pada masing-masing variabel.

1. Variabel Motivasi (x)

a. Devinisi Konseptual:

Motivasi adalah kekuatan yang mendorong seseorang melakukan suatu tindakan yang timbul pada diri pekerja waktu dia menjalankan tugasnya. Karyawan dapat bekerja karena tertarik dan senang pada pekerjaannya dan merupakan keinginan yang terdapat pada seorang individu untuk melakukan suatu tindakan-tindakan. Agar lebih bertanggung jawab dan dapat lebih maksimal untuk memenuhi kebutuhan insentif, pokok, dan sosial pekerja.

b. Devinisi Operasional:

Motivasi adalah kekuatan yang mendorong seseorang melakukan suatu tindakan yang timbul pada diri pekerja waktu dia menjalankan tugasnya. Karyawan dapat bekerja karena tertarik dan senang pada pekerjaannya dan merupakan keinginan yang terdapat pada seorang individu untuk melakukan suatu tindakan-tindakan. Agar lebih bertanggung jawab dan dapat lebih maksimal untuk memenuhi kebutuhan insentif, pokok, dan sosial pekerja yang diukur melalui instrumen yang berupa kuisioner yang berisi pertanyaan terhadap karyawan BPKD yang terdiri dari : (1) Kebutuhan insentif (2) Tanggung jawab (3) Pemenuhan kebutuhan pokok (4) Pemenuhan kebutuhan sosial.

2. Variabel prestasi kerja (y):

a. Devinisi Konseptual:

Prestasi kerja adalah hasil kerja sama disiplin, dan kreatifitas seorang karyawan untuk menghasilkan kualitas dan kuantitas dalam melaksanakan tugasnya memiliki jiwa kepemimpinan. Serta catatan yang diperoleh dari fungsi-fungsi pekerjaan sebagai tingkat kecakapan, kesetiaan, dan kejujuran seseorang pada tugas-tugas yang mencangkup pada pekerjaannya.

b. Devinisi Operasional:

Prestasi kerja adalah hasil kerja sama disiplin, dan kreatifitas seorang karyawan untuk menghasilkan kualitas dan kuantitas dalam melaksanakan tugasnya memiliki jiwa kepemimpinan. Serta catatan yang diperoleh dari fungsi-fungsi pekerjaan sebagai tingkat kecakapan, kesetiaan, dan kejujuran seseorang pada tugas-tugas yang mencangkup pada pekerjaannya yang diukur melalui instrument berupa kuisioner yang berisi pertanyaan terhadap karyawan BPKD yang terdiri dari : (1) Kecakapan (2) Kerjasama (3) Kesetiaan (4) Kejujuran (5) Kedisiplinan (6) Kreatifitas (7) Kepemimpinan.

\section{Populasi dan Sampel Populasi}

Menurut Sugiono (2010) populasi adalah wilayah generalisasi yang terdiri atas objek atau subjek yang mempunyai kualitas dan karakteristik tertentu yang ditetapkan oleh peneliti untuk dipelajari dan kemudian ditarik kesimpulannya. Adapun populasi yang diambil dari 
peneltian ini adalah karyawan pada Badan Pengelolaan Keuangan Daerah Kota Metro yang berjumlah 86 orang.

\section{Sampel}

Menurut Sugiono (2010) sampel adalah bagian dari jumlah dan karakteristik yang dimiliki oleh populasi tersebut. Dalam penelitian ini sampel yang digunakan adalah karyawan pada Badan Pengelolaan Keuangan Daerah Kota Metro. Untuk menentukan ukuran sampel yang dibutuhkan, digunakan rumus Slovin sebagai berikut:

Sumber: Umar, (2003)

$$
n=\frac{n}{1+n(e)^{2}}
$$

keterangan :

$\mathrm{n}$ : ukuran sampel

$\mathrm{n}$ : banyak populasi

$\mathrm{e}^{2}$ : kelonggaran ketidak telitian karena kesalahan pengambilan sampel yang dapat ditolerir. Konstanta yang digunakan dalam penelitian ini adalah $\mathrm{e}=5 \%$

Berdasarkan data yang ada, diketahui bahwa karyawan pada Badan Pengelolaan Daerah Kota Metro adalah sebanyak 86 orang. Dari data tersebut maka dapat diketahui ukuran sampel yang digunakan dalam penelitian ini adalah sebagai berikut:

$$
n=\frac{86}{1+86(0,05)^{2}}=70
$$

Jadi sampel yang digunakan dalam penelitian ini adalah 70 orang karyawan. Pengambilan sampel ini dengan menggunakan teknik Probability Sampling yaitu mengetahui besarnya induk populasi dan setiap unsur atau kelompok harus memiliki peluang yang sama untuk dijadikan sampel. Dengan pendekatan Stratified Random Sampling yaitu dikatakan simple (sederhana) karna pengambilan sampel dilakukan secara acak tanpa memperhatikan strata yang ada dalam populasi. Alasannya adalah bahwa populasi bersifat homogen.

\section{Alat Analisis Data Uji Validitas}

Uji validitas digunakan untuk mengukur salah atau valid tidaknya suatu kuisioner. Menurut Ravianto (2001) Suatu kuisioner dikatakan valid jika pertanyaan pada kuisioner mampu mengungkapkan sesuatu yang diukur oleh kuisioner tersebut. Diantaranya koefisien korelasi product moment dari karl pearson, yaitu:

$$
\mathrm{r}_{\mathrm{xy}}=\frac{N \sum x y-\sum x \sum y}{\sqrt{\left.\left(N \sum x^{2}-\left(\sum X\right)^{2}\right)-N \sum y^{2}-\left(\sum y\right)^{2}\right)}}
$$

\section{Uji Realibitas}

Uji realibitas adalah alat untuk mengukur suatu kuisioner yang merupakan indikator dari variabel atau konstruk. Suatu kuisioner dapat dikatkan reliabel atau handal jika jawaban seseorang terhadap pertanyaan adalah konsisten atau stabil. Menurut Panggabean (2002) "Suatu instrument penelitian dikatakan mempunyai nilai reliabilitas yang tinggi apabila ters yang dibuat mempunyai hasil yang konsisten dalam mengukur yang hendak diukur".

Reliabilitas menunjukan sejauh mana hasil pengukuran dengan alat tersebut dapat dipercaya. Berdasarkan pendapat Arikunto (2006). Penelitian dianggap dapat diandalkan bila memberikan hasil yang konsisten untuk pengukuran yang sama. Formula yang digunakan untuk menguji reliabilitas instrumen dalam penelitian ini adalah Alfa $(\alpha)$ dari Chonbarch, yaitu:

$$
\mathrm{r}_{11}=\left[\frac{k}{k-1}\right] \cdot\left[1-\frac{\sum \sigma t^{2}}{\sigma 2_{t}}\right.
$$


Dimana:

Rumus varians $=\sigma^{2}=\frac{\sum x^{2-\frac{\left(\sum x\right)^{2}}{N}}}{N}$

\section{Hipotesis Statistik}

Hipotesis statistik adalah pernataan statistik tentang populasi yang diteliti. Jika menguji hipotesis penelitian dengan perhitungan statistik. Maka rumusan hipotesis tersebut perlu diubah kedalam rumusan hipotesis penelitian hanya dituliskan salah satu saja yaitu hipotesis alterntif (Ha) atau hipotesis nol (Ho).

Ho diterima, bila $\rho$ hitung $>\rho$ tabel dan tolak Ho, bila $\rho$ dihitung $\leq$ dari $\rho$ tabel.

Keputusan yang akan diambil adalah sebagai berikut:

Jika $\rho$ dihitung $\leq \rho$ tabel: maka hipotesis nol (Ho) diterima dan menolak hipotesis $\quad$ tif (Ha).

Jika $\rho$ dihitung $>\rho$ tabel: maka hipotesis nol (Ho) ditolak dan menerima hipotesis alternatif (Ha).

\section{HASIL PENELITIAN DAN PEMBAHASAN}

\section{Uji Kualitas Data}

Variabel yang disajikan dalam bagian ini meliputi variabel motivasi (x)

1. Uji Validitas

Dalam analisis ini apabila item dikatakan valid berati reliabel, untuk mengetahui tingkat validitas perhatikan angka tabel Corrected Item-Total Correlation yang terdapat pada lampiran, yang merupakan korelasi antara skor item nilai $r_{\text {hitung }}$ atau $r_{\text {hitung }}>$ dari $r_{\text {tabel }}$ maka item tersebut adalah valid.

Tabel 1. Hasil output variabel motivasi (x)

\section{Item-Total Statistics}

\begin{tabular}{|l|r|r|r|r|}
\hline & $\begin{array}{c}\text { Scale Mean if } \\
\text { Item Deleted }\end{array}$ & $\begin{array}{c}\text { Scale Variance } \\
\text { if Item Deleted }\end{array}$ & $\begin{array}{c}\text { Corrected Item- } \\
\text { Total } \\
\text { Correlation }\end{array}$ & $\begin{array}{c}\text { Cronbach's Alpha if } \\
\text { Item Deleted }\end{array}$ \\
\hline VAR00001 & 109.67 & 268.108 & .630 & .743 \\
VAR00002 & 109.70 & 259.372 & .835 & .733 \\
VAR00003 & 109.84 & 267.439 & .597 & .743 \\
VAR00004 & 109.67 & 260.340 & .798 & .734 \\
VAR00005 & 109.74 & 258.745 & .840 & .732 \\
VAR00006 & 109.90 & 266.439 & .664 & .741 \\
VAR00007 & 109.74 & 280.078 & .140 & .758 \\
VAR00008 & 109.77 & 259.280 & .798 & .733 \\
VAR00009 & 109.97 & 265.304 & .727 & .740 \\
VAR00010 & 109.70 & 287.228 & -.100 & .766 \\
VAR00011 & 109.77 & 259.280 & .798 & .733 \\
VAR00012 & 109.97 & 265.304 & .727 & .740 \\
VAR00013 & 110.03 & 280.086 & .176 & .757 \\
VAR00014 & 109.77 & 259.280 & .798 & .733 \\
VAR00015 & 109.94 & 264.373 & .751 & .739 \\
VAR00016 & 56.80 & 71.235 & 1.000 & .898 \\
\hline
\end{tabular}


Tabel 2. Pengujian hasil validitas motivasi (x) sebagai berikut:

\begin{tabular}{|c|c|c|c|}
\hline Item & $\mathrm{r}_{\text {hitung }}$ & $\mathrm{r}_{\text {tabel }}$ & Keputusan \\
\hline 1 & 630 & 0,213 & Valid \\
\hline 2 & 835 & 0,213 & Valid \\
\hline 3 & 597 & 0,213 & Valid \\
\hline 4 & 798 & 0,213 & Valid \\
\hline 5 & 840 & 0,213 & Valid \\
\hline 6 & 664 & 0,213 & Valid \\
\hline 7 & 140 & 0,213 & Tidak Valid \\
\hline 8 & 798 & 0,213 & Valid \\
\hline 9 & 727 & 0,213 & Valid \\
\hline 10 & 100 & 0,213 & Tidak Valid \\
\hline 11 & 798 & 0,213 & Valid \\
\hline 12 & 727 & 0,213 & Valid \\
\hline 13 & 176 & 0,213 & Tidak valid \\
\hline 14 & 798 & 0,213 & Valid \\
\hline 15 & 751 & 0,213 & Valid \\
\hline
\end{tabular}

Pada variabel motivasi (x), uji validitas yang tidak valid adalah item $7=0,140$, item $10=0,100$. Item 13=0,176, sehingga harus dikeluarkan atau dibuang dari perhitungan. Dari 15 pertanyaan terdapat 3 item yang tidak valid, sedangkan 12 item lainnya valid.

Tabel 3. Hasil Output Variabel Prestasi Kerja (y)

Item-Total Statistics

\begin{tabular}{|l|r|r|r|r|}
\hline & $\begin{array}{c}\text { Scale Mean if } \\
\text { Item Deleted }\end{array}$ & $\begin{array}{c}\text { Scale Variance if } \\
\text { Item Deleted }\end{array}$ & $\begin{array}{c}\text { Corrected Item- } \\
\text { Total Correlation }\end{array}$ & $\begin{array}{c}\text { Cronbach's Alpha if } \\
\text { Item Deleted }\end{array}$ \\
\hline VAR00001 & 105.79 & 229.272 & .309 & .734 \\
VAR00002 & 105.23 & 214.614 & .800 & .711 \\
VAR00003 & 105.73 & 227.824 & .385 & .731 \\
VAR00004 & 105.16 & 215.033 & .771 & .712 \\
VAR00005 & 105.11 & 221.900 & .495 & .724 \\
VAR00006 & 105.39 & 222.066 & .631 & .722 \\
VAR00007 & 105.59 & 230.536 & .259 & .736 \\
VAR00008 & 105.23 & 214.730 & .796 & .712 \\
VAR00009 & 105.87 & 226.838 & .355 & .731 \\
VAR00010 & 104.97 & 238.695 & -.046 & .747 \\
VAR00011 & 105.56 & 221.729 & .473 & .724 \\
VAR00012 & 105.34 & 221.504 & .636 & .722 \\
VAR00013 & 105.89 & 225.146 & .423 & .728 \\
VAR00014 & 105.49 & 215.935 & .655 & .715 \\
VAR00015 & 105.41 & 222.797 & .536 & .724 \\
VAR00016 & 54.54 & 59.556 & 1.000 & .829 \\
\hline
\end{tabular}

Tabel 4. Pengujian Hasil Validitas Prestasi Kerja (y)

\begin{tabular}{|c|c|c|c|}
\hline No. Item & $\mathrm{R}_{\text {hitung }}$ & $\mathrm{R}_{\text {tabel }}$ & Keputusan \\
\hline 1 & 309 & 0,213 & Valid \\
\hline
\end{tabular}




\begin{tabular}{|c|c|c|c|}
\hline No. Item & $\mathrm{R}_{\text {hitung }}$ & $\mathrm{R}_{\text {tabel }}$ & Keputusan \\
\hline 2 & 800 & 0,213 & Valid \\
\hline 3 & 385 & 0,213 & Valid \\
\hline 4 & 771 & 0,213 & Valid \\
\hline 5 & 495 & 0,213 & Valid \\
\hline 6 & 631 & 0,213 & Valid \\
\hline 7 & 259 & 0,213 & Valid \\
\hline 8 & 796 & 0,213 & Valid \\
\hline 9 & 355 & 0,213 & Valid \\
\hline 10 & 046 & 0,213 & Tidak Valid \\
\hline 11 & 473 & 0,213 & Valid \\
\hline 12 & 636 & 0,213 & Valid \\
\hline 13 & 423 & 0,213 & Valid \\
\hline 14 & 655 & 0,213 & Valid \\
\hline 15 & 536 & 0,213 & Valid \\
\hline
\end{tabular}

Pada variabel prestasi kerja (y), uji validitas yang tidak valid adalah item $10=0,046$ sehingga harus dikeluarkan atau dibuang dari perhitungan. Dari 15 pertanyaan terdapat 1 item yang tidak valid, sedangkan 14 item lainnya valid.

2. Uji Reliabilitas

Menurut Notoadmodjo (2003) suatu instrumen dikatakan mempunyai nilai realibilitas yang tinggi apabila tes yang dibuat mempunyai hasil yang konsisten dalam mengukur yang hendak diukur.

Kategori:

$0.70-0.80$ : sangat kuat

$0.60-0.70$ : kuat

$0.40-0.60$ : sedang

$0.10-0.40:$ lemah

Tabel 5. Uji Hasil Reliabilitas Motivasi (x)

Reliability Statistics

\begin{tabular}{|c|c|c|c|}
\hline \multirow[t]{5}{*}{ Cronbach's Alpha } & Part 1 & $\begin{array}{l}\text { Value } \\
\mathrm{N} \text { of Items }\end{array}$ & $\begin{array}{r}.860 \\
8^{\mathrm{a}}\end{array}$ \\
\hline & Part 2 & Value & .538 \\
\hline & & $\mathrm{N}$ of Items & $8^{b}$ \\
\hline & & Total $\mathrm{N}$ of Items & 16 \\
\hline & & Correlation Between Forms & .950 \\
\hline \multirow{3}{*}{$\begin{array}{l}\text { Spearman-Brown } \\
\text { Coefficient }\end{array}$} & & Equal Length & .974 \\
\hline & & Unequal Length & .974 \\
\hline & & $\begin{array}{l}\text { Guttman Split-Half } \\
\text { Coefficient }\end{array}$ & .808 \\
\hline
\end{tabular}

a. The items are: VAR00001, VAR00002, VAR00003, VAR00004, VAR00005,

VAR00006, VAR00007, VAR00008.

b. The items are: VAR00009, VAR00010, VAR00011, VAR00012, VAR00013,

VAR00014, VAR00015, VAR00016. 
Pengujian realiabilitas untuk variabel motivasi (x), kita lihat nilai cronbach's alpha $=$ 0,860 yang terdapat pada katagori sangat kuat bila dibandingkan dengan $r_{\text {tabel }}(0,213)$. Maka $r_{\text {hitung }}>$ dari pada $r_{\text {tabel }}$ dengan demikian bias disimpulkan bahwa angket tersebut realibel.

Tabel 6. Uji Hasil Reliabilitas Prestasi Kerja (y)

Reliability Statistics

\begin{tabular}{|c|c|c|c|}
\hline \multirow[t]{5}{*}{ Cronbach's Alpha } & Part 1 & $\begin{array}{l}\text { Value } \\
\mathrm{N} \text { of Items }\end{array}$ & $\begin{array}{r}.789 \\
8^{\mathrm{a}}\end{array}$ \\
\hline & Part 2 & Value & .531 \\
\hline & & $\mathrm{N}$ of Items & $8^{b}$ \\
\hline & & Total $\mathrm{N}$ of Items & 16 \\
\hline & & Correlation Between Forms & .887 \\
\hline \multirow{3}{*}{$\begin{array}{l}\text { Spearman-Brown } \\
\text { Coefficient }\end{array}$} & & Equal Length & .940 \\
\hline & & Unequal Length & .940 \\
\hline & & $\begin{array}{l}\text { Guttman Split-Half } \\
\text { Coefficient }\end{array}$ & .777 \\
\hline
\end{tabular}

a. The items are: VAR00001, VAR00002, VAR00003, VAR00004, VAR00005, VAR00006, VAR00007, VAR00008.

b. The items are: VAR00009, VAR00010, VAR00011, VAR00012, VAR00013, VAR00014, VAR00015, VAR00016.

Pengujian realiabilitas untuk variabel prestasi kerja (y), kita lihat nilai cronbach's alpha $=0,789$ yang terdapat pada katagori sangat kuat bila dibandingkan dengan $r_{\text {tabel }}(0,213)$. Maka $\mathrm{r}_{\text {hitung }}>$ dari pada $\mathrm{r}_{\text {tabel }}$ dengan demikian bisa disimpulkan bahwa angket tersebut realibel.

\section{ANALISIS DATA}

Analisis Kualitatif

Sebagaimana telah dikemukakan, bahwa pemberian motivasi merupakan hal yang sangat esensial. Keberhasilan dari pembinaan motivasi ini diharapkan akan memberikan sumbangan atau kontribusi yang cukup besar bagi terciptanya peningkatan presasi kerja karyawan yang pada akhirnya mendukung pencapaian tujuan suatu organisasi.

Hal ini disebabkan karena dengan diberikannya motivasi pada karyawan, maka mereka akan bekerja dengan penuh semangat. Dengan semangat kerja yang tinggi diharapkan prestasi kerja karyawan dapat ditingkatkan.

\section{Analisis Kualintatif}

Untuk mengetahui sejauh mana mana hubungan motivasi (x) dengan prestasi kerja (y), dengan menggunakan korelasi Rank Spearman. Korelasi ini dilakukan dengan mengurutkan (menyusun ranking dari masing-masing variabel) kemudian data ranking tersebut diuji apakah terdapat hubungan antara keduanya. Ini merupakan suatu penelitian untuk mengetahui apakah ada hubungan motivasi dengan prestasi kerja karyawan.

Tabel 7. Tabel Kerja Rank Spearman

\begin{tabular}{|c|c|c|c|c|c|c|}
\hline \multirow{2}{*}{ No } & \multicolumn{2}{|c|}{ Variabel Penelitian } & \multirow{2}{*}{$\mathbf{r x}$} & $\mathbf{2 y}$ & $\mathbf{b i}$ & \multirow{2}{*}{ bi2 } \\
\cline { 2 - 3 } & $\mathbf{x}$ & $\mathbf{y}$ & & & & \\
\hline $\mathbf{1}$ & 42 & 61 & 40,5 & 6,5 & 34 & 1156 \\
\hline $\mathbf{2}$ & 52 & 60 & 20 & 9,5 & 10,5 & 110,25 \\
\hline
\end{tabular}




\begin{tabular}{|c|c|c|c|c|c|c|}
\hline \multirow{2}{*}{ No } & \multicolumn{2}{|c|}{ Variabel Penelitian } & \multirow{2}{*}{$\mathbf{r x}$} & \multirow{2}{*}{ ry } & \multirow{2}{*}{ bi } & \multirow{2}{*}{ bi2 } \\
\hline & $\mathbf{x}$ & $\mathbf{y}$ & & & & \\
\hline 3 & 54 & 64 & 14,5 & 1,5 & 13 & 169 \\
\hline 4 & 54 & 59 & 34,5 & 17 & -2.5 & 6,25 \\
\hline 5 & 44 & 59 & 25 & 17 & 17,5 & 306,25 \\
\hline 6 & 49 & 59 & 46 & 17 & 8 & 64 \\
\hline 7 & 54 & 60 & 14,5 & 9,5 & 5 & 25 \\
\hline 8 & 44 & 56 & 34,5 & 24 & 10,5 & 110,25 \\
\hline 9 & 50 & 59 & 22 & 17 & 5 & 25 \\
\hline 10 & 60 & 55 & 4 & 26 & -22 & 484 \\
\hline 11 & 38 & 46 & 50 & 45,5 & 4,5 & 20,25 \\
\hline 12 & 54 & 59 & 14,5 & 17 & -2.5 & 6,25 \\
\hline 13 & 38 & 47 & 50 & 43,5 & 6,5 & 42,25 \\
\hline 14 & 60 & 56 & 4 & 24 & -20 & 400 \\
\hline 15 & 36 & 44 & 63 & 49,5 & 13,5 & 182,25 \\
\hline 16 & 42 & 59 & 40,5 & 17 & 23,5 & 552.25 \\
\hline 17 & 36 & 39 & 63 & 67,5 & -4.5 & 20,25 \\
\hline 18 & 48 & 53 & 29,5 & 28,5 & 1 & 1 \\
\hline 19 & 48 & 51 & 29,5 & 34 & -9.5 & 90,25 \\
\hline 20 & 42 & 50 & 40,5 & 37 & 3.5 & 12,25 \\
\hline 21 & 42 & 48 & 40,4 & 41 & -0.5 & 0,25 \\
\hline 22 & 48 & 48 & 29,5 & 41 & -11.5 & 132,25 \\
\hline 23 & 42 & 46 & 40,5 & 45,5 & -5 & 25 \\
\hline 24 & 54 & 59 & 14,5 & 17 & -2.5 & 6,25 \\
\hline 25 & 42 & 43 & 40,5 & 54 & -13.5 & 182,25 \\
\hline 26 & 42 & 48 & 40,5 & 41 & -0.5 & 0,25 \\
\hline 27 & 42 & 59 & 40,5 & 17 & 23,5 & 552,25 \\
\hline 28 & 54 & 61 & 14,5 & 6,5 & 8 & 64 \\
\hline 29 & 36 & 43 & 63 & 54 & 9 & 81 \\
\hline 30 & 36 & 43 & 63 & 54 & 9 & 81 \\
\hline 31 & 60 & 60 & 4 & 9,5 & -5.5 & 30,25 \\
\hline 32 & 36 & 43 & 63 & 54 & 9 & 81 \\
\hline 33 & 36 & 42 & 63 & 60 & 3 & 9 \\
\hline 34 & 54 & 60 & 14,5 & 9,5 & 5 & 25 \\
\hline 35 & 36 & 43 & 63 & 54 & 9 & 81 \\
\hline 36 & 36 & 39 & 63 & 67,5 & -4.5 & 20,25 \\
\hline 37 & 37 & 39 & 54 & 67,5 & -13.5 & 182,25 \\
\hline 38 & 54 & 53 & 14,5 & 28,5 & -14 & 196 \\
\hline 39 & 36 & 40 & 63 & 65 & -2 & 4 \\
\hline 40 & 36 & 43 & 63 & 54 & 9 & 81 \\
\hline 41 & 48 & 47 & 29,5 & 43,5 & -14 & 196 \\
\hline 42 & 38 & 41 & 50 & 63,5 & -13.5 & 182,25 \\
\hline 43 & 36 & 42 & 63 & 60 & 3 & 9 \\
\hline
\end{tabular}




\begin{tabular}{|c|c|c|c|c|c|c|}
\hline \multirow{2}{*}{ No } & \multicolumn{2}{|c|}{ Variabel Penelitian } & \multirow{2}{*}{$\mathbf{r x}$} & \multirow{2}{*}{ ry } & \multirow{2}{*}{ bi } & \multirow{2}{*}{ bi2 } \\
\hline & $\mathbf{x}$ & $\mathbf{y}$ & & & & \\
\hline 44 & 60 & 56 & 4 & 24 & -20 & 400 \\
\hline 45 & 36 & 42 & 63 & 60 & 3 & 9 \\
\hline 46 & 48 & 50 & 29,5 & 37 & -7.5 & 56,25 \\
\hline 47 & 42 & 44 & 40,5 & 49,5 & -9 & 81 \\
\hline 48 & 42 & 51 & 40,5 & 34 & 6,5 & 42,25 \\
\hline 49 & 60 & 60 & 4 & 9,5 & -5.5 & 30,25 \\
\hline 50 & 36 & 41 & 63 & 63,5 & -0.5 & 0,25 \\
\hline 51 & 36 & 42 & 63 & 60 & 3 & 9 \\
\hline 52 & 54 & 63 & 14,5 & 4 & 10,5 & 110,25 \\
\hline 53 & 50 & 53 & 22 & 28,5 & -6.5 & 42,25 \\
\hline 54 & 36 & 43 & 63 & 54 & 9 & 81 \\
\hline 55 & 60 & 53 & 4 & 28,5 & -24.5 & 600,25 \\
\hline 56 & 39 & 42 & 46,5 & 60 & -13.5 & 182,25 \\
\hline 57 & 37 & 45 & 54 & 47,5 & 6,5 & 42,25 \\
\hline 58 & 54 & 62 & 14,5 & 5 & 9,5 & 90,25 \\
\hline 59 & 37 & 39 & 54 & 67,5 & -13.5 & 182,25 \\
\hline 60 & 49 & 51 & 25 & 34 & -9 & 81 \\
\hline 61 & 49 & 52 & 25 & 31,5 & -6.5 & 42,25 \\
\hline 62 & 59 & 59 & 5 & 17 & -12 & 144 \\
\hline 63 & 38 & 45 & 50 & 47,5 & 2,5 & 6,25 \\
\hline 64 & 38 & 36 & 50 & 70 & -20 & 400 \\
\hline 65 & 55 & 52 & 6 & 31,5 & -25.5 & 650,25 \\
\hline 66 & 50 & 50 & 22 & 37 & -15 & 225 \\
\hline 67 & 39 & 43 & 46,5 & 54 & -7.5 & 56,25 \\
\hline 68 & 60 & 64 & 4 & 1,5 & 2,5 & 6,25 \\
\hline 69 & 48 & 57 & 29,5 & 22 & 7.5 & 56,25 \\
\hline 70 & 45 & 49 & 33 & 39 & -6 & 36 \\
\hline Jumlah & 3183 & 3530 & 1636 & 1524 & -207.5 & 5275.25 \\
\hline
\end{tabular}

Berdasarkan perhitungan jumlah dari ranking masing-masing variabel di proleh nilai $\sum b i^{2}=5275,25$ maka diperoleh nilai Koefisien korelasi Rank Spearman, Supranto (2009) adalah sebagai berikut:

$$
\begin{aligned}
& \rho=1-\frac{6 \sum b i^{2}}{n\left(n^{2}-1\right)} \\
& \rho=1-\frac{6 x 5275,25}{70\left(70^{2}-1\right)} \\
& \rho=1-\frac{31654,5}{70(4900-1)}
\end{aligned}
$$




$$
\begin{aligned}
& \rho=1-\frac{31654,5}{70(4899)} \\
& \rho=1-\frac{31654,5}{342930} \\
& \rho=1-0,0923 \\
& \rho=0,9077
\end{aligned}
$$

Berdasarkan hasil perhitungan menggunakan Koefisien korelasi Rank Spearman diperoleh nilai rho $(\rho)=0,9077$, berdasarkan kriteria penafsirannya Sugiono (2010), besaran korelasi itu masuk dala kategori sangat kuat.

\section{Uji Hipotesis (Uji Z)}

Uji signifikasi dilakukan bertujuan untuk mengetahui pengaruh positif dan signifikan dari variabel independen terhadap variabel depemden. Adapun rumus yang digunakan adalah sebagai berikut:

$$
\begin{gathered}
Z_{\text {hit }}=\frac{\frac{\rho}{1}}{\sqrt{n-1}} \\
Z_{\text {hit }}=\frac{\frac{0,907}{1}}{\sqrt{70-1}} \\
Z_{\text {hit }}=\frac{\frac{0,907}{1}}{8,3} \\
Z_{\text {hit }}=7,539
\end{gathered}
$$

Berdasarkan hasil perhitungan menggunakan rumus $Z_{\text {hitung }}$ diperoleh nilai 7,539 dan $Z_{\text {tabel }}$ untuk dk $(70)=68$ adalah 2,581, sehingga nilai $Z_{\text {hitung }}>$ nilai $Z_{\text {tabel }}$, yang didapat dari taraf signifikasi $(Z)=1 \%(\alpha=0,01)$.

Berdasarkan interpretasi hasil hitung:

1. Jika nilai $Z_{\text {hitung }}>$ nilai $Z_{\text {tabel, }}$ yang didapat dari taraf signifikasi $(Z)=1 \%(\alpha=0,01)$, dan maka $\mathrm{H}_{\mathrm{o}}$ ada di daerah penolakan, berarti $\mathrm{H}_{1}$ diterima artinya antara variabel $\mathrm{X}$ dan $\mathrm{Y}$ ada hubungan yang signifika.

2. Jika nilai $Z_{\text {hitung }} \leq$ nilai $Z_{\text {tabel }}$ yang didapat dari taraf signifikasi $(Z)=! \%(\alpha=0,01)$, maka $H_{o}$ ada didaerah penerimaan, berarti $\mathrm{H}_{1}$ ditolak artinya antara variabel $\mathrm{x}$ dan y tidak ada hubungan yang signifikan.

Maka hasil ini menunjukan bahw $\mathrm{H}_{\mathrm{o}}$ ada didaerah penolakan, berarti $\mathrm{H}_{1}$ diterima artinya antara variabel $\mathrm{x}$ dan $\mathrm{y}$ ada hungan yang signifikan. Atau terdapat hubungan antara motivasi dan prestasi kerja karyawan.

\section{Hasil dan Pembahasan}

Berdasarkan hasil perhitungan menggunakan koefisien korelasi Rank Spearman diproleh adanya hubungan antara motivasi dengan prestasi kerja karyawan dalam tingkat yang kuat. Hal ini sesuai dengan hipotesis yang menyatakan terdapat hubungan yang signifikan antara motivasi kerja dengan prestasi kerja karyawan.

Hubungan antara motivasi kerja dengan prestasi kerja karyawan sesuai dengan teori yang menyatakan bahwa motivasi merupakan kekuatan yang mendorong seseorang melakukan suatu tindakan yang timbul pada diri pekerja waktu dia menjalankan tugas pekerjaannya, 
sehinggga motivasi kerja yang baik akan mempengaruhi motivasi kerja seorang karyawan, semakin motivasi iadalam bekerja maka prestasi kerja juga akan meningkat.

Berdasarkan hasil perhitungan menggunakan uji $\mathrm{Z}$ antara variabel motivasi kerja dan prestasi kerja karyawan ada hubungan yang signifikan. Dengan melihat signifikasi variabel motivasi kerja pada uji $\mathrm{Z}$ disimpulkan bahwa motivasi kerja memiliki hubungan yang signifikan terhadap prestasi kerja karyawan. Hal ini sesuai dengan hipotesis yang menyatakan motivasi kerja memiliki hubungan dengan prestasi kerja karyawan.

Dengan motivasi kerja yang baik maka dapat membuat pegawai lebih giat dalam bekerja sehingga pekerjaan dapat diselesaikan dengan tepat sesuai standar yang benar dan dalam sekala waktu yang ditentukan. Motivasi kerja yang baik akan menciptakan tim kerja yang bekerja secara individu maupun saling bekerja sama tim work dengan baik. Berdasarkan hal tersebut maka motivasi kerja dalam suatu instansi/perusahaan sangat penting untuk diperhatikan.

Hasil penelitian terdahulu oleh Dito, et.al. (2010) tentang Pengaruh Kompensasi Terhadap Kinerja Karyawan PT. Slamet Langgeng Purbalingga Dengan Motivasi Kerja Sebagai Variabel Intervening dengan hasil motivasi berpengaruh positif dan signifikan terhadap kinerja karyawan, dan hasil penelitian Nurhayati (2013) tentang Pengaruh kompensasi terhadap produktivitas karyawan pada PD Semangat Jaya, Pesawaran dengan hasil Kompensasi mempunyai pengaruh signifikan terhadap Produktivitas Kerja.

\section{KESIMPULAN DAN SARAN \\ Kesimpulan}

Berdasarkan hasil analisis dan pembahasan yang telah dikemukakan Penulis dapat menyimpulkan sebagai berikut:

Motivasi kerja secara signifikan mempunyai pengaruh terhadap prestasi kerja karyawan. Hasil ini sesuai hipotesis yang menyatakan bahwa motivasi kerja memiliki hubungan yang signifikan dengan prestasi kerja karyawan.

\section{Saran}

Berdasarkan kesimpulan, maka disarankan kepada para pengambil kebijakan Badan Pengelolaan Keuangan Daerah (BPKD) untuk dapat memberikan skala prioritas bagi peningkatan sumberdaya manusia agar motivasi kerja pegawai dapat lebih baik melalui upayaupaya pelatihan, memberikan imbalan bagi yang berprestasi, dan hukuman bagi pegawai yang kurang atau tidak berusaha untuk meningkatkan motivasi diri. Hal ini dilakukan mengingat adanya pengaruh yang signifikan antara motivasi kerja terhadap prestasi kerja karyawan. Dari segi prestasi kerja karyawan, perlu terus ditingkatkan faktor-faktor yang dapat meningkatkan motivasi kerja pegawai, karena peningkatan motivasi kerja pegawai, berkaitan dengan pencapaian tujuan instansi dengan cara memberikan stimulant bagi peningkatan motivasi kerja dan faktor lain yang berhubungan dengan motivasi kerja karyawan.

\section{DAFTAR PUSTAKA}

Anoraga, Pandji dan Piji Pakarta. 2006 Pengantar Pasar Modal. Edisi Revisi.Jakarta: Rinika Cipta.

Ardana, I Komang. Ni Wayan Mujiati, I Wayan Mudiarta, 2012. Manajemen Sumberdaya Manusia. Jakarta: PT Gramedia.

Arikunto, Suharsimi. 2006. Prosedur Penelitian Suatu Pendekatan Praktik. Jakarta: PT Rineka Cipta. 
Dito, Anoki Herdian dan Lataruva, Eisha. 2010. Pengaruh Kompensasi Terhadap Kinerja Karyawan dengan Motivasi Kerja Sebagai Variabel Intervening pada PT. Slamet Langgeng Purbalingga. Undergraduate Thesis, Universitas Diponegoro.

Hasibuan, Melayu S.P. 2001., Manajemen Sumber Daya Manusia, Edisi Revisi. Jakarta: Bumi Aksara.

Ibrahim, Masud. Impact Of Motivation On Employee Performance. The Case Of Some Selected Micro Finance Companies In Ghana. International Journal of Economics, Commerce and Management. United Kingdom. United Kingdom. Vol. III, Issue 11, November 2015.

Mangkunegara, A.A. Anwar Prabu. 2005. Manajemen Sumber Daya Manusia Perusahaan. Bandung: PT Remaja Rosdakarya.

Notoadmodjo. 2003. Manajemen Sumber Daya Manusia. Jakarta: PT. Gramedia.

Nurhayati. 2013. Pengaruh Kompensasi Terhadap Produktivitas Karyawan pada PD Semangat Jaya, Pesawaran. Skripsi, Fakultas Ekonomi Universitas Muhammadiyah Metro

Ofelia Robescu and Alina-Georgiana Iancu. 2016. The Effects of Motivation on Employees Performance in Organizations. Valahian Journal of Economic Studies. Volume 7, Issue 2.

Pamela Akinyi Omollo. 2015. Supervised by Dr. Oloko Jomo. Effect of motivation on employee performance of commercial banks in Kenya: A case study of Kenya Commercial Bank in Migori County. Kenyatta University of Agriculture and Technology Kenya. International Journal of Human Resource Studies. ISSN 21623058. Vol. 5, No. 2.

Panggabean, Mutiara S. 2002. Manajemen Sumber Daya Manusia. Bogor: Ghalia Indonesia.

Ravianto, J. 2001. Produktivitas dan Manajemen, Edisi Revisi. Jakarta: Bumi Aksara.

Siagian, Sondang, MPA. 2008. Manajemen Sumber Daya Manusia. Bandung: Bumi Aksara.

Siswanto, Bedjo. 2002. Manajemen tenaga kerja Indonesia: Pendekatan Administratif dan Operasional. Jakarta: Bumi Aksara.

Sugiono. 2010. Metode Penelitian dan Kualitatif dan R \& D. Bandung: Alfabet.

Supranto, J. 2009. Statistik Teori dan Aplikasi, Edisi 7. Jakarta: Erlangga.

Sutrisno, Edy. 2011. Menejemen Sumber Daya Manusia. Jakarta: Kencana.

Umar, Husen. 2003. Metodelogi Penelitian Untuk Skripsi dan Tesis Bisnis. Jakarta: PT. Gramedia Pustaka.

Wiludjeng, Sri S.P. 2007. Pengantar Manajemen. Yogyakarta: Graha Ilmu.

Wirantha, I Made. 2006. Metodelogi Penelitian Sosial Ekonomi. Yogyakarta: C.V Andi Offset.

Wursanto. 2000. Kearsipan. Yogyakarta: Kanisius. 